九州大学学術情報リポジトリ

Kyushu University Institutional Repository

\title{
Is Walnut Import Liberalization Benefical or Harmful to Japan?
}

Suzuki, Nobuhiro

Faculty of Agriculture, Kyushu University

https://doi.org/10.5109/4728

出版情報：九州大学大学院農学研究院紀要. 51 (1)，pp.173-180，2006-02-01. Faculty of Agriculture, Kyushu University

バージョン :

権利関係 : 


\title{
Is Walnut Import Liberalization Beneficial or Harmful to Japan?
}

\author{
Nobuhiro SUZUKI* \\ Laboratory of Quantitative Analysis of Agribusiness Organization, Division of Industrial Organization of \\ Agribusiness, Department of Agricultural and Resource Economics, Faculty of Agriculture, \\ Kyushu University, Fukuoka 812-8581, Japan \\ (Received October 28, 2005 and accepted November 16, 2005)
}

\begin{abstract}
The import tariff rate for walnuts in Japan is $10 \%$, which is significantly higher than tariffs for other nuts imported to Japan. This report examines the question of whether walnut import liberalization is beneficial or harmful to Japan. The answer is walnut import liberalization benefits Japan. A simulation model is developed which considers the competition between the US and China in the Japanese shelled walnut, shelled sweet almond, and pistachio markets. Tariff elimination of walnut imports to Japan would have increased U.S. exports by $4.7 \%$ and generate a gain of 397 million yen for Japanese users in 2002 . There are virtually no negative effects on Japanese walnut growers because there are only a few farmers specialized in walnut production and specialized farmers have their own niche markets completely separated from imports. Our results also reveal that the promotion money collected from U.S. walnut growers is effective in increasing U.S. exports to Japan. Specifically, we estimate the incremental gains to U.S. walnut growers to be over three times higher than the incremental promotion costs.
\end{abstract}

\section{INTRODUCTION}

The import tariff rate for walnuts in Japan is $10 \%$, which is significantly higher than tariffs for other nuts imported to Japan. Moreover, since 1994 there has been a gradual reduction in tariff rates for all nuts except walnuts, which remains at $10 \%$, and macadamia nuts, which remains at $5 \%$. In this article, we address the question of whether import liberalization for walnuts is beneficial or harmful to Japan. In addressing this question, we focus on welfare impacts on the two parties impacted by trade policy: consumers and growers. Specifically, we estimate how much Japanese walnut users and consumers will gain and how much growers will lose from lower import prices due to tariff elimination.

To measure these gains and losses due to tariff liberalization, an econometric model is developed that incorporates competition among exporters, and competition between walnuts and other nuts. Based on the discussion in the next section, we exclude the Japanese domestic walnut supply and prices in the model because the domestic supply covers only less than one percent of the total walnut demand in Japan and there is no significant competition between domestic and imported walnuts. The model explicitly considers competition between exporters from the United States and China because these two countries account for almost all walnut imports to Japan. The model also includes the two main substitutes for walnuts in Japan: sweet almond and pistachio nuts, which are imported from the United States. The econometric model is then used to simulate three scenarios: (1) tariff elimination for all countries, (2) tariff elimination for only China, and (3) tariff elimination for only the United States. In addition, our model incorporates promotion variables into the import demand equations to account for the impact of U.S.

* Corresponding author (E-mail: suzukino@agr.kyushu-u.ac.jp) export promotion on demand. Hence, a secondary objective is to estimate the effectiveness of the check-off money from California walnut farmers.

\section{JAPANESE DOMESTIC WALNUT SUPPLY SITUATION}

As shown in Table 1, Japanese domestic walnut supply (in-shell and shelled walnuts) has been decreasing over time. In 1986, Japan produced 548 tons of walnuts, which fell to 101 tons in 2002 . In 2002, the domestic supply of 101 tons was less than $1 \%$ of total walnut imports (10,247 ton). Put differently, over $99 \%$ of Japanese walnut demand (10,348tons) is met by imports.

Table 1. Domestic Walnut Supply in Japan

\begin{tabular}{ccccc}
\hline & $\begin{array}{c}\text { Total } \\
\text { Production } \\
\text { (t) }\end{array}$ & $\begin{array}{c}\text { Market } \\
\text { Supply } \\
\text { (t) }\end{array}$ & $\begin{array}{c}\text { Nagano's } \\
\text { Production } \\
\text { (t) }\end{array}$ & $\begin{array}{c}\text { Nagano's } \\
\text { Share } \\
\text { (\%) }\end{array}$ \\
\hline & [a] & [b] & [c] & [a]/[c] \\
1986 & 861 & 548 & 550 & 63.9 \\
1987 & 897 & 558 & 580 & 64.7 \\
1988 & 869 & 577 & 590 & 67.9 \\
1989 & 565 & 365 & 300 & 53.1 \\
1990 & 787 & 502 & 490 & 62.3 \\
1991 & 702 & 456 & 460 & 65.5 \\
1992 & 662 & 374 & 450 & 68.0 \\
1993 & 622 & 319 & 430 & 69.1 \\
1994 & 593 & 305 & 400 & 67.5 \\
1995 & 441 & 221 & 265 & 60.1 \\
1996 & 442 & 223 & 278 & 62.9 \\
1997 & 407 & 197 & 247 & 60.7 \\
1998 & 311 & 152 & 188 & 60.5 \\
1999 & 346 & 221 & 240 & 69.4 \\
2000 & n.a. & n.a. & n.a. & n.a. \\
2001 & 204 & 100 & 180 & 88.2 \\
2002 & 243 & 101 & 200 & 82.3 \\
\hline
\end{tabular}

Source: Fruits and Vegetables Division, Ministry of Agriculture, Forestry, and Fisheries 
Table 2. The US and China's positions over Shelled Walnut Imports to Japan

\begin{tabular}{|c|c|c|c|c|c|c|c|c|}
\hline & \multicolumn{4}{|c|}{ Shelled Walnut Imports to Japan (kg) } & \multicolumn{4}{|c|}{ Share (\%) } \\
\hline & US & China & Others & Total & US & China & Others & Total \\
\hline 1988 & $1,643,222$ & $2,078,082$ & 59,510 & $3,780,814$ & 43.5 & 55.0 & 1.6 & 100 \\
\hline 1989 & $1,624,336$ & $1,406,467$ & 30,000 & $3,060,803$ & 53.1 & 46.0 & 1.0 & 100 \\
\hline 1990 & $1,989,856$ & $1,365,468$ & 5,600 & $3,360,924$ & 59.2 & 40.6 & 0.2 & 100 \\
\hline 1991 & $2,634,974$ & $1,325,904$ & 20,500 & $3,981,378$ & 66.2 & 33.3 & 0.5 & 100 \\
\hline 1992 & $3,595,179$ & $1,711,787$ & 19,987 & $5,326,953$ & 67.5 & 32.1 & 0.4 & 100 \\
\hline 1993 & $4,600,257$ & $1,862,809$ & 6,000 & $6,469,066$ & 71.1 & 28.8 & 0.1 & 100 \\
\hline 1994 & $4,820,892$ & $2,059,216$ & 1,230 & $6,881,338$ & 70.1 & 29.9 & 0.0 & 100 \\
\hline 1995 & $6,861,036$ & $1,631,156$ & 23,200 & $8,515,392$ & 80.6 & 19.2 & 0.3 & 100 \\
\hline 1996 & $6,862,602$ & $2,246,915$ & 460 & $9,109,977$ & 75.3 & 24.7 & 0.0 & 100 \\
\hline 1997 & $6,158,167$ & $2,345,094$ & 500 & $8,503,761$ & 72.4 & 27.6 & 0.0 & 100 \\
\hline 1998 & $6,809,933$ & $1,737,733$ & 9,628 & $8,557,294$ & 79.6 & 20.3 & 0.1 & 100 \\
\hline 1999 & $6,940,199$ & $1,596,191$ & 5,660 & $8,542,050$ & 81.2 & 18.7 & 0.1 & 100 \\
\hline 2000 & $8,199,784$ & $1,192,445$ & 12,258 & $9,404,487$ & 87.2 & 12.7 & 0.1 & 100 \\
\hline 2001 & $7,269,433$ & $1,559,551$ & 16,886 & $8,845,870$ & 82.2 & 17.6 & 0.2 & 100 \\
\hline 2002 & $8,447,324$ & $1,461,119$ & 26,310 & $9,934,753$ & 85.0 & 14.7 & 0.3 & 100 \\
\hline 2003 & $8,303,890$ & $1,266,673$ & 24,361 & $9,594,924$ & 86.5 & 13.2 & 0.3 & 100 \\
\hline
\end{tabular}

Source: Japan Exports and Imports, Ministry of Finance.

Table 3. Import Prices of Shelled Walnuts, Shelled Sweet Almond, and Pistachio Nuts

\begin{tabular}{|c|c|c|c|c|c|c|c|c|c|c|c|c|c|c|c|c|}
\hline \multirow[b]{3}{*}{1988} & \multicolumn{4}{|c|}{ CIF Prices (yen/kg) } & \multicolumn{4}{|c|}{ Tariffs $(1+$ Rate $)$} & \multicolumn{4}{|c|}{ CIF Prices with Tariffs (yen $/ \mathrm{kg}$ ) } & \multicolumn{4}{|c|}{ CIF Prices with Tariffs (China $=100$ ) } \\
\hline & \multirow{2}{*}{$\begin{array}{c}\begin{array}{c}\text { US } \\
\text { Walnuts }\end{array} \\
520.7\end{array}$} & \multirow{2}{*}{$\begin{array}{c}\text { China } \\
\text { Walnuts }\end{array}$} & \multicolumn{2}{|c|}{ Almond Pistachio } & \multirow{2}{*}{$\begin{array}{c}\begin{array}{c}\text { US } \\
\text { Walnuts }\end{array} \\
1.1\end{array}$} & $\begin{array}{l}\text { China } \\
\text { Walnuts }\end{array}$ & \multicolumn{2}{|c|}{ Almond Pistachio } & \multicolumn{2}{|c|}{$\begin{array}{c}\text { US China } \\
\text { Walnuts Walnuts }\end{array}$} & \multicolumn{2}{|c|}{ Almond Pistachio } & \multicolumn{2}{|c|}{$\begin{array}{c}\text { US China } \\
\text { Walnuts Walnuts }\end{array}$} & \multicolumn{2}{|c|}{ Almond Pistachio } \\
\hline & & & 444.8 & 628.2 & & 1.1 & 1.04 & 1 & 572.8 & 417.7 & 462.6 & 628.2 & 137.1 & 100.0 & 110.8 & 150.4 \\
\hline 1989 & 586.0 & 392.9 & 497.6 & 696.0 & 1.1 & 1.1 & 1.04 & 1 & 644.6 & 432.1 & 517.5 & 696.0 & 149.2 & 100.0 & 119.8 & 161.1 \\
\hline 1990 & 614.2 & 417.4 & 566.1 & 710.4 & 1.1 & 1. & 1.04 & 1 & 675.6 & 459.1 & 588.8 & 710.4 & 147.2 & 100.0 & 128.2 & 154.7 \\
\hline 1991 & 585.0 & 395.4 & 441.3 & 580.5 & 1.1 & 1.1 & 1.04 & 1 & 643.5 & 435.0 & 458.9 & 580.5 & 147.9 & 100.0 & 105.5 & 133.5 \\
\hline 1992 & 580.4 & 388.4 & 484.0 & 605.6 & 1.1 & 1.1 & 1.04 & 1 & 638.4 & 427.2 & 503.3 & 605.6 & 149.4 & 100.0 & 117.8 & 141.8 \\
\hline 1993 & 633.3 & 385.9 & 494.4 & 506.0 & 1.1 & 1.1 & 1.04 & 1 & 696.6 & 424.5 & 514.2 & 506.0 & 164.1 & 100.0 & 121.1 & 119.2 \\
\hline 1994 & 561.6 & 345.4 & 548.4 & 413.6 & 1.1 & 1.1 & 1.04 & 1 & 617.8 & 379.9 & 570.3 & 413.6 & 162.6 & 100.0 & 150.1 & 108.9 \\
\hline 1995 & 432.9 & 273.3 & 435.7 & 388.8 & 1.1 & 1.1 & 1.037 & 1 & 476.2 & 300.6 & 451.8 & 388.8 & 158.4 & 100.0 & 150.3 & 129.3 \\
\hline 1996 & 656.6 & 355.5 & 732.9 & 480.8 & 1.1 & 1.1 & 1.035 & 1 & 722.2 & 391.1 & 758.6 & 480.8 & 184.7 & 100.0 & 194.0 & 122.9 \\
\hline 1997 & 748.0 & 459.5 & 663.5 & 582.2 & 1.1 & 1.1 & 1.032 & 1 & 822.7 & 505.4 & 684.7 & 582.2 & 162.8 & 100.0 & 135.5 & 115.2 \\
\hline 1998 & 684.7 & 468.1 & 603.3 & 632.2 & 1.1 & 1.1 & 1.029 & 1 & 753.2 & 514.9 & 620.8 & 632.2 & 146.3 & 100.0 & 120.6 & 122.8 \\
\hline 1999 & 517.9 & 372.5 & 468.3 & 518.3 & 1.1 & 1.1 & 1.027 & 1 & 569.7 & 409.7 & 481.0 & 518.3 & 139.0 & 100.0 & 117.4 & 126.5 \\
\hline 2000 & 427.1 & 362.5 & 332.3 & 558.6 & 1.1 & 1.1 & 1.024 & 1 & 469.8 & 398.7 & 340.2 & 558.6 & 117.8 & 100.0 & 85.3 & 140.1 \\
\hline 2001 & 635.5 & 409.7 & 383.1 & 511.5 & 1.1 & 1.1 & 1.024 & 1 & 699.1 & 450.7 & 392.3 & 511.5 & 155.1 & 100.0 & 87.0 & 113.5 \\
\hline 2002 & 595.4 & 465.1 & 401.9 & 579.1 & 1.1 & 1.1 & 1.024 & 1 & 655.0 & 511.6 & 411.5 & 579.1 & 128.0 & 100.0 & 80.4 & 113.2 \\
\hline 2003 & 549.5 & 441.5 & 426.7 & 576.9 & 1.1 & 1.1 & 1.024 & 1 & 604.5 & 485.7 & 437.0 & 576.9 & 124.5 & 100.0 & 90.0 & 118.8 \\
\hline
\end{tabular}

Source: Japan Exports and Imports, Ministry of Finance.

The main reason for declining domestic production is there are only a few growers specialized in walnut production in Japan. Most domestic production comes from growers with only one or two walnut trees on the edge of their field or garden. As the walnut trees become taller, their management becomes more difficult. In particular, walnut trees are prone to insects (such as Hyphantria cunea) and some diseases (such as sooty mold). If growers do nothing to prevent this, insects and diseases will spread over all their field jeopardizing other crops. Therefore, a choice a lot of growers have made is to cut down the walnut trees. Another problem is instability and volatility of production caused by frost in April, which is also a reason for cutting walnut trees.

Growers specialized in walnut production have their own niche markets which are completely separated from imports. An official from a cooperative explained the fo- lowing situation. There are several growers specialized in walnut production in the official's town, with total annual production about two tons equally split between in-shell and shelled marketings. Shelling is done by hand, and if the shelled shape is symmetric, it can be sold to special bakeries. If the shape is not good, it is sold to soba noodle restaurants serving "walnut soba noodles." The average selling price of shelled walnuts for such special utilization is about 2,000 yen per kilogram, or four times higher than import prices. Thus, these growers have their niche markets completely differentiated from imports. According to the cooperative spokesman, there is no competition between these producers and imports at all since the niche market is so small.

For the above reasons, we can consider that there is no significant competition between domestic and 
imported walnuts in the Japanese market and walnut tariff elimination will have no negative impacts on Japanese domestic supply.

\section{IMPORT DEMAND COMPETITION MODEL}

Walnut imports are divided into two categories: inshell and shelled since 1988. Because about 97 to $99 \%$ of recent walnut imports to Japan are classified into the shelled category, we focus on shelled walnut imports after 1988. As shown in Table 2, 99.7 to $99.9 \%$ of total shelled walnut imports comes from the two countries: the US and China. The US share has been increasing over time, or $44 \%$ in 1988 to $87 \%$ in 2003 , while the CIF prices of imports from the US are much higher than China's prices, raging widely from $18 \%$ higher in 2000 to 85\% higher in 1996, as shown in Table 3.

We should incorporate competition between the US and China over the Japanese walnut market into our model. Considering the huge import price differences between the two countries, imported walnuts from the two countries are not homogeneous. There is some product differentiation, and they are imperfect substitutes for each other.

In addition, we should consider competition between walnuts and other nuts. The other major nuts are sweet almond and pistachio nuts. As shown in Table 3 , shelled sweet almond prices and pistachio prices with tariffs are usually lower than the US walnut prices and they are more close to China's walnut prices. Because too many variables makes our analysis unstable with data only after the year 1988, we incorporate total imports and whole average prices of these two nuts, instead of using country-by-country data. Actually, as $98 \%$ of shelled sweet almond and $89 \%$ of pistachio nuts come from the US, we can consider that total data stands for the US data.

As other factors influencing Japanese walnut import demand, we consider the US promotion activities for Japan and consumers' income level in Japan. Because the California Walnut Commission is collecting promotion money from walnut farmers, we can use the amounts of check-off money utilized for promotion in Japan as a proxy variable for promotion activities. We consider only one-period carry over effects of promotion activities because of annual data. The California walnut check-off money used in Japan may affects Japanese demand for Chinese walnuts and other nuts, too.

Thus, our model structure using double-log functions with constant elasticities, can be described as follows.

Equation (1) for the US walnut import demand: $\mathrm{LOG}(\mathrm{Q} W U S N)=C(11)+C(12) * \mathrm{LOG}\left(P W U S^{*} T W\right)+$ $C(13) * \mathrm{LOG}\left(P W C^{*} T W\right)+C(14) * \mathrm{LOG}\left(P A T^{*} T A\right)+$ $C(15) * \mathrm{LOG}(P P T)+C(16) * \mathrm{LOG}(E X P N)+C(17) *$ $\operatorname{LOG}(C W C N)+C(18) * \mathrm{LOG}(C W C N(-1))$

Equation (2) for Chinese walnut import demand: $\mathrm{LOG}(Q W C N)=C(21)+C(22) * \mathrm{LOG}(P W U S * T W)+$
$C(23) * \mathrm{LOG}\left(P W C^{*} T W\right)+C(24) * \mathrm{LOG}\left(P A T^{*} T A\right)+$ $C(25) * \mathrm{LOG}(P P T)+C(26) * \mathrm{LOG}(E X P N)+C(27) *$ $\mathrm{LOG}(C W C N)+C(28) * \mathrm{LOG}(C W C N(-1))$

Equation (3) for almond import demand: $\mathrm{LOG}(Q A T N)=C(31)+C(32) * \mathrm{LOG}\left(P W U S^{*} T W\right)+$ $C(33) * \mathrm{LOG}\left(P W C^{*} T W\right)+C(34) * \mathrm{LOG}\left(P A T^{*} T A\right)+$ $C(35) * \mathrm{LOG}(P P T)+C(36) * \mathrm{LOG}(E X P N)+C(37) *$ $\mathrm{LOG}(C W C N)+C(38) * \mathrm{LOG}(C W C N(-1))$

Equation (4) for pistachio import demand:

$\mathrm{LOG}(Q P T N)=C(41)+C(42) * \mathrm{LOG}\left(P W U S^{*} T W\right)+$ $C(43) * \mathrm{LOG}(P W C * T W)+C(44) * \mathrm{LOG}\left(P A T^{*} T A\right)+$ $C(45) * \mathrm{LOG}(P P T)+C(46) * \mathrm{LOG}(E X P N)+C(47) *$ $\mathrm{LOG}(C W C N)+C(48) * \mathrm{LOG}(C W C N(-1))$

where dependent variables are

QWUSN = per capita shelled walnut quantity imported from the US;

$Q W C N=$ per capita shelled walnut quantity imported from China;

$Q A T N=$ per capita import quantity of shelled sweet almond;

$Q P T N=$ per capita import quantity of pistachio nuts,

and common explanatory variables are

$P W U S=$ shelled walnut CIF (cost, insurance and freight) price imported from the US;

$T W=1+$ tariff rate for shelled walnuts;

$P W C=$ shelled walnut CIF price imported from China;

$P A T=$ shelled sweet almond CIF price;

$T A=1+$ tariff rate for shelled sweet almond;

$P P T=$ shelled pistachio CIF price;

$E X P N=$ average per capita expenditure;

$C W C N=$ Japan promotion dollars (per capita) collected from California walnut farmers;

$C W C N(-1)=C W C N$ in the previous year. LOG represents natural logarithm, and * implies multiplying the variables. More detailed explanation for variables is shown in Tables 8 and 9.

Because the explanatory variables are common for all four equations, the best estimation method would be the Seemingly Unrelated Regression in this case. Variables are omitted when estimated coefficients are not significantly different from zero. The final estimation results are as follows. More detailed figures are shown in Table 10. Because the Japanese income level data is not yet available for the year 2003, the estimation period is from 1988 to 2002, except for Equation (2) in which the EXPN variable was omitted.

Equation (1):
LOG $($ QWUSN $)=-79.435-0.478 *$ LOG $\left(P W U S^{*} T W\right)$ $(-11.7)(-2.87)$
$+6.120 * \mathrm{LOG}($ EXPN $)+0.393 * \mathrm{LOG}(C W C N)$
(12.3)
$+0.121 * \operatorname{LOG}(C W C N(-1))$
(1.73)

R-squared $=0.954$ Adjusted R-squared $=0.936 \quad \mathrm{DW}=$ 1.17 
Equation (2):

$$
\begin{gathered}
\mathrm{LOG}(Q W C N)=0.671 * \mathrm{LOG}(P W U S * T W)-0.709 * \mathrm{LOG} \\
(1.67) \quad(-2.40) \\
(P W C * T W)+0.407 * \mathrm{LOG}(P A T * T A) \\
+0.299 * \mathrm{LOG}(C W C N)-0.305 * \mathrm{LOG}(C W C N(-1))
\end{gathered}
$$

$\mathrm{R}$-squared $=0.690 \quad$ Adjusted R-squared $=0.578 \quad \mathrm{DW}=$ 2.05

Equation (3):

$\operatorname{LOG}(Q A T N)=18.840+0.289 * \mathrm{LOG}\left(P W C^{*} T W\right)$

(3.87) (2.04)

$-0.382 * \operatorname{LOG}(P A T * T A)-0.938 * \operatorname{LOG}(E X P N)$

$$
(-4.24) \quad(-2.72)
$$

$\mathrm{R}-\mathrm{squared}=0.582$ Adjusted R-squared $=0.468 \quad \mathrm{DW}=$ 1.10

Equation (4):

$$
\begin{aligned}
\operatorname{LOG}(Q P T N)= & 70.513+0.973 * \operatorname{LOG}(P A T * T A) \\
& (3.82) \quad(2.92) \\
-1.491 * \mathrm{LOG}(P P T)-4.548 * \operatorname{LOG}(E X P N) & (-3.43) \quad(-3.68)
\end{aligned}
$$

R-squared $=0.556$ Adjusted R-squared $=0.434 \quad \mathrm{DW}=$ 1.10

Estimated coefficients means elasticities, or Equation (1) implies that a 1\% reduction of imported US walnut prices will generate $0.48 \%$ increases in Japanese demand for the US walnuts. Chinese walnuts, sweet almond, and pistachio nuts will have no significant effects on US walnut demand in Japan. This seems consistent with the fact that the US walnut prices are much higher than other nut prices. Japanese consumer income level will have very positive effects on the US walnuts. A $1 \%$ increase in the CWC (California Walnut Commission) check-off money will increase the US walnut exports to Japan by $0.51 \%$, including one-year carryover effects.

Equation (2) implies that a $1 \%$ reduction of imported US walnut prices will generate $0.67 \%$ decreases in Japanese demand for Chinese walnuts, a $1 \%$ reduction of imported Chinese walnut prices will generate $0.71 \%$ increases in Japanese demand for Chinese walnuts, and a $1 \%$ reduction of imported almond prices will generate $0.41 \%$ decreases in Japanese demand for Chinese walnuts. Thus, Chinese walnuts are more sensitive to prices of other nuts compared to the US walnuts. The results indicate that simultaneous elimination of $10 \%$ walnut tariffs for both China and the US will have only small increases in Chinese walnut imports to Japan because about $7.1 \%$ increase are almost cancelled out by $6.7 \%$ decreases. Japanese consumer income level will have no significant effects on Chinese walnuts while it has very positive effects on the US walnuts. This is consistent with the fact that the US walnut prices are much higher than Chinese prices. A $1 \%$ increase in the CWC check-off money will decrease China's walnut exports to Japan by $0.006 \%$, by canceling out positive and negative effects for two years.
Equation (3) indicates that a $1 \%$ reduction of imported Chinese walnut prices will generate $0.29 \%$ decreases in Japanese import demand for sweet almond, and a $1 \%$ reduction of imported sweet almond prices will generate $0.38 \%$ increases in Japanese import demand for sweet almond. Sweet almond might be a inferior good because Japanese consumer income level will have negative effects on Japanese import demand for sweet almond.

Equation (4) indicates that a $1 \%$ reduction of imported sweet almond prices will generate $0.97 \%$ decreases in Japanese import demand for pistachio nuts, and a $1 \%$ reduction of imported pistachio prices will generate $1.49 \%$ increases in Japanese import demand for pistachio nuts. Pistachio nuts might be also a inferior good because Japanese consumer income level will have negative effects on Japanese import demand for pistachio nuts.

\section{SIMULATION ANALYSIS OF TARIFF ELIMINATION}

Because tariff elimination will increase the US and Chinese walnut exports to Japan, the US and Chinese walnut price may rise due to tighter supply and demand. We should incorporate walnut supply functions in the US and China into our simulation model in order to capture such price changes. However, the share of the US exports to Japan in the US total walnut production is only two to three percent, and the Chinese percentage is much smaller. Therefore, we can regard Japan as a "small country" in terms of walnut imports. Thus, using only the estimated four demand Equation (1) to (4), we can simulate the effects of tariff elimination on Japanese users of imported nuts and foreign exporters.

We set three scenarios: simultaneous tariff elimination for all countries and all nuts under a possible WTO agreement; preferential tariff elimination only for Chinese walnuts under a possible East Asian Free Trade Agreement; preferential tariff elimination only for the US nuts under a possible Japan-US Free Trade Agreement. In the third scenario, the US nuts include shelled walnuts, shelled sweet almond, and pistachio nuts because most imported almond and pistachio nuts come from the US. We simulate the situation that tariffs were zero in each year since 1988 until 2002.

The results are shown in Table 4, 5, and 6. Table 4 shows percent changes in quantities imported. If all tariffs were eliminated, the US walnut imports would have increased by $4.7 \%$ each year. Increases in Chinese walnut imports would have been only $0.4 \%$ because of competition with the US walnuts nuts and almond. Almond imports would have decreased because effects of eliminating $10 \%$ Chinese walnut tariffs were larger compared to elimination effects of lower tariffs for almond. Pistachio imports would have decreased because of effects of eliminating almond tariffs, because pistachio prices would have no changes since tariffs were already zero for pistachio nuts.

Table 5 and 6 show benefits to Japanese users of 
Table 4. Percent Changes in Import Volume Caused by Tariff Elimination

\begin{tabular}{|c|c|c|c|c|c|c|c|c|c|c|c|c|}
\hline \multirow[b]{2}{*}{ Case } & \multicolumn{4}{|c|}{ Zero for all } & \multicolumn{4}{|c|}{ Zero for China } & \multicolumn{4}{|c|}{ Zero for US } \\
\hline & $\begin{array}{c}\text { US } \\
\text { Walnuts }\end{array}$ & $\begin{array}{c}\text { China } \\
\text { Walnuts }\end{array}$ & Almond & Pistachio & $\begin{array}{c}\text { US } \\
\text { Walnuts }\end{array}$ & $\begin{array}{c}\text { China } \\
\text { Walnuts }\end{array}$ & Almond & Pistachio & $\begin{array}{c}\text { US } \\
\text { Walnuts }\end{array}$ & $\begin{array}{c}\text { China } \\
\text { Walnuts }\end{array}$ & Almond & Pistachio \\
\hline 1988 & 104.7 & 100.4 & 98.8 & 96.3 & 100.0 & 107.0 & 97.3 & 100.0 & 104.7 & 92.3 & 101.5 & 96.3 \\
\hline 1989 & 104.7 & 100.4 & 98.8 & 96.3 & 100.0 & 107.0 & 97.3 & 100.0 & 104.7 & 92.3 & 101.5 & 96.3 \\
\hline 1990 & 104.7 & 100.4 & 98.8 & 96.3 & 100.0 & 107.0 & 97.3 & 100.0 & 104.7 & 92.3 & 101.5 & 96.3 \\
\hline 1991 & 104.7 & 100.4 & 98.8 & 96.3 & 100.0 & 107.0 & 97.3 & 100.0 & 104.7 & 92.3 & 101.5 & 96.3 \\
\hline 1992. & 104.7 & 100.4 & 98.8 & 96.3 & 100.0 & 107.0 & 97.3 & 100.0 & 104.7 & 92.3 & 101.5 & 96.3 \\
\hline 1993 & 104.7 & 100.4 & 98.8 & 96.3 & 100.0 & 107.0 & 97.3 & 100.0 & 104.7 & 92.3 & 101.5 & 96.3 \\
\hline 1994 & 104.7 & 100.4 & 98.8 & 96.3 & 100.0 & 107.0 & 97.3 & 100.0 & 104.7 & 92.3 & 101.5 & 96.3 \\
\hline 1995 & 104.7 & 100.4 & 98.6 & 96.5 & 100.0 & 107.0 & 97.3 & 100.0 & 104.7 & 92.4 & 101.4 & 96.5 \\
\hline 1996 & 104.7 & 100.4 & 98.6 & 96.7 & 100.0 & 107.0 & 97.3 & 100.0 & 104.7 & 92.5 & 101.3 & 96.7 \\
\hline 1997 & 104.7 & 100.4 & 98.5 & 97.0 & 100.0 & 107.0 & 97.3 & 100.0 & 104.7 & 92.6 & 101.2 & 97.0 \\
\hline 1998 & 104.7 & 100.4 & 98.4 & 97.3 & 100.0 & 107.0 & 97.3 & 100.0 & 104.7 & 92.7 & 101.1 & 97.3 \\
\hline 1999 & 104.7 & 100.4 & 98.3 & 97.4 & 100.0 & 107.0 & 97.3 & 100.0 & 104.7 & 92.8 & 101.0 & 97.4 \\
\hline 2000 & 104.7 & 100.4 & 98.2 & 97.7 & 100.0 & 107.0 & 97.3 & 100.0 & 104.7 & 92.9 & 100.9 & 97.7 \\
\hline 2001 & 104.7 & 100.4 & 98.2 & 97.7 & 100.0 & 107.0 & 97.3 & 100.0 & 104.7 & 92.9 & 100.9 & 97.7 \\
\hline 2002 & 104.7 & 100.4 & 98.2 & 97.7 & 100.0 & 107.0 & 97.3 & 100.0 & 104.7 & 92.9 & 100.9 & 97.7 \\
\hline
\end{tabular}

Table 5. Users' Benefits and Sellers' Losses from Tariff Elimination (nominal)

(Unit: Million Yen)

\begin{tabular}{|c|c|c|c|c|c|c|}
\hline \multirow{2}{*}{$\begin{array}{l}\text { Case } \\
\text { Country }\end{array}$} & \multicolumn{2}{|c|}{ Zero for all } & \multicolumn{2}{|c|}{ Zero for China } & \multicolumn{2}{|c|}{ Zero for US } \\
\hline & US & China & US & China & US & China \\
\hline 1988 & 81.5 & 67.4 & 0.0 & 69.6 & 81.5 & -51.6 \\
\hline 1989 & 100.8 & 56.9 & 0.0 & 58.8 & 100.8 & -43.6 \\
\hline 1990 & 133.4 & 68.8 & 0.0 & 71.1 & 133.4 & -52.8 \\
\hline 1991 & 186.4 & 64.5 & 0.0 & 66.6 & 186.4 & -49.4 \\
\hline 1992 & 227.5 & 61.9 & 0.0 & 64.0 & 227.5 & -47.5 \\
\hline 1993 & 258.5 & 66.2 & 0.0 & 68.4 & 258.5 & -50.8 \\
\hline 1994 & 293.5 & 71.9 & 0.0 & 74.3 & 293.5 & -55.1 \\
\hline 1995 & 272.0 & 44.7 & 0.0 & 46.2 & 272.0 & -33.8 \\
\hline 1996 & 394.7 & 79.8 & 0.0 & 82.4 & 394.7 & -59.7 \\
\hline 1997 & 480.9 & 92.1 & 0.0 & 95.2 & 480.9 & -67.9 \\
\hline 1998 & 535.7 & 93.3 & 0.0 & 96.4 & 535.7 & -67.8 \\
\hline 1999 & 425.0 & 54.2 & 0.0 & 56.0 & 425.0 & -39.0 \\
\hline 2000 & 384.4 & 43.8 & 0.0 & 45.3 & 384.4 & -31.0 \\
\hline 2001 & 444.4 & 64.9 & 0.0 & 67.0 & 444.4 & -46.0 \\
\hline 2002 & 397.2 & 58.2 & 0.0 & 60.1 & 397.2 & -41.2 \\
\hline
\end{tabular}

Table 6. Users' Benefits and Sellers' Losses from Tariff Elimination (1995 price)

(Unit: Million Yen)

\begin{tabular}{|c|c|c|c|c|c|c|}
\hline \multirow{2}{*}{$\begin{array}{l}\text { Case } \\
\text { Country }\end{array}$} & \multicolumn{2}{|c|}{ Zero for all } & \multicolumn{2}{|c|}{ Zero for China } & \multicolumn{2}{|c|}{ Zero for US } \\
\hline & US & China & US & China & US & China \\
\hline 1988 & 75.0 & 62.0 & 0.0 & 64.1 & 75.0 & -47.6 \\
\hline 1989 & 91.6 & 51.7 & 0.0 & 53.5 & 91.6 & -39.7 \\
\hline 1990 & 119.7 & 61.8 & 0.0 & 63.8 & 119.7 & -47.4 \\
\hline 1991 & 167.0 & 57.8 & 0.0 & 59.7 & 167.0 & -44.3 \\
\hline 1992 & 204.4 & 55.6 & 0.0 & 57.5 & 204.4 & -42.6 \\
\hline 1993 & 236.1 & 60.5 & 0.0 & 62.5 & 236.1 & -46.4 \\
\hline 1994 & 269.8 & 66.1 & 0.0 & 68.3 & 269.8 & -50.6 \\
\hline 1995 & 272.0 & 44.7 & 0.0 & 46.2 & 272.0 & -33.8 \\
\hline 1996 & 392.3 & 79.3 & 0.0 & 81.9 & 392.3 & -59.3 \\
\hline 1997 & 481.8 & 92.3 & 0.0 & 95.4 & 481.8 & -68.1 \\
\hline 1998 & 555.1 & 96.7 & 0.0 & 99.9 & 555.1 & -70.3 \\
\hline 1999 & 434.6 & 55.5 & 0.0 & 57.3 & 434.6 & -39.9 \\
\hline 2000 & 402.9 & 45.9 & 0.0 & 47.4 & 402.9 & -32.5 \\
\hline 2001 & 462.0 & 67.4 & 0.0 & 69.7 & 462.0 & -47.8 \\
\hline 2002 & 413.3 & 60.5 & 0.0 & 62.5 & 413.3 & -42.9 \\
\hline Total & 4577.7 & 957.9 & 0.0 & 989.6 & 4577.7 & -713.0 \\
\hline
\end{tabular}

Table 7. Effectivenes of CWC Assessments

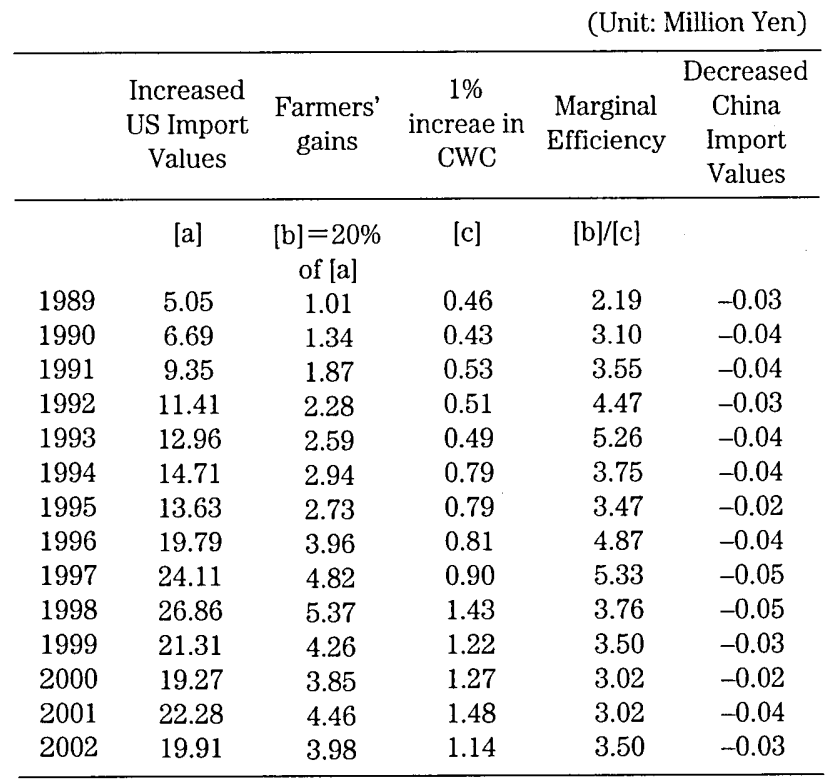

imported walnuts. Benefits to walnut users are measured by lower price merits multiplied by the average of import quantities between before and after tariff elimination, or users' benefits $=$ (observed price - price without tariff) multiplied by (simulated import volume + observed import volume)/2. This definition is almost the same as increases in "consumer surplus."

Table 5 shows values in nominal terms. It indicates that Japanese users would have gained 397 million yen from tariff elimination of the US walnuts, and 58 million yen from tariff elimination of Chinese walnuts in 2002. If tariffs were eliminated only for China, Japanese users' gains would have been only 60 million yen from Chinese walnuts in 2002. If tariffs were eliminated only for the US, Japanese users would have had the same $397 \mathrm{mil}-$ lion-yen gains from tariff elimination of the US walnuts, but they would have had no gains from Chinese walnuts in 2002. It should be noted that the negative figures in the last column in Table 5 are not losses of Japanese 
users, but losses of China's exporters measured by (simulated import volume-observed import volume) multiplied by observed price.

Table 6 shows values in real terms deflated by wholesale food price indices set as $1995=100$ in Japan. It indicates that Japanese users would have gained 4,578 million yen from tariff elimination of the US walnuts, and 958 million yen from tariff elimination of Chinese walnuts in total from 1988 to 2002.

Our simulation also suggests that simultaneous liberalization will be more beneficial to Japanese walnut users than preferential liberalization under regional free trade agreements.

\section{PROMOTION EFFECTIVENESS}

We also simulate effectiveness of promotion activities implemented by the CWC check-off money assessed on California walnut farmers. In Table 7 , increases in imported values of the US walnuts associated with a $1 \%$ increase in the CWC money are compared with the amounts of the $1 \%$ increase in the CWC money.
Because not all increased values belong to walnut farmers, we assume that only $20 \%$ of increased sales belong to farmers. The CWC promotion money is provided by the US currency, and we convert them into the Japanese yen applying 1 dollar $=120$ yen for all years in order to avoid effects of fluctuating currency appreciation.

In 2002, a $1 \%$ increase in the CWC money is 1.14 million yen and associated increases in import values of the US walnuts are 19.91 million yen. Assumed farmers' gains are $20 \%$ of 19.19 million yen, or 3.98 million yen. Then, marginal efficiency of the CWC promotion money for California walnuts is estimated at 3.50 in 2002. This means that the CWC promotion activities are very effective for California walnut farmers.

\section{CONCLUSIONS}

This report addressed the question as to whether walnut tariff elimination is beneficial to Japan or not. Our answer is that walnut import liberalization benefits Japan. A simulation model was developed incorporating competition between the US and China in the Japanese

Table 8. Model Variables

\begin{tabular}{|c|c|c|c|}
\hline Variables & Definitions & Unit & Sources \\
\hline cwc & $\begin{array}{l}\text { Japan promotion dollars collected from } \\
\text { California walnut farmers }\end{array}$ & dollar & California Walnut Commission \\
\hline map & $\begin{array}{l}\text { Japan promotion dollars provided by the USDA } \\
\text { Market Access Program }\end{array}$ & dollar & California WaInut Commission \\
\hline adt & cwc +map & dollar & California Walnut Commission \\
\hline qwus & Shelled walnut quantity imported from the US & $\mathrm{kg}$ & Japan Exports and Imports, Ministry of Finance \\
\hline vwus & Shelled walnut value imported from the US & 1,000 yen & Japan Exports and Imports, Ministry of Finance \\
\hline pwus & $\begin{array}{l}\text { Shelled walnut CIF (cost, insurance and freight) } \\
\text { price imported from the US }\end{array}$ & yen $/ \mathrm{kg}$ & Japan Exports and Imports, Ministry of Finance \\
\hline qwe & Shelled walnut quantity imported from China & $\mathrm{kg}$ & Japan Exports and Imports, Ministry of Finance \\
\hline vwc & Shelled walnut value imported from China & 1,000 yen & Japan Exports and Imports, Ministry of Finance \\
\hline pwc & $\begin{array}{l}\text { Shelled walnut CIF(cost, insurance and freight) } \\
\text { price imported from China }\end{array}$ & yen/kg & Japan Exports and Imports, Ministry of Finance \\
\hline pop & Total population in Japan & person & Japan Statistical Yearbook, Ministry of Public Management \\
\hline wpif & Wholesale price index for food & $1995=100$ & Wholesale Price Indices, The Bank of Japan \\
\hline $\exp$ & Average per household expenditure & 1,000 yen & $\begin{array}{l}\text { Family Income and Expenditure Survey, Ministry of Public } \\
\text { Management }\end{array}$ \\
\hline $\mathrm{n}$ & Average persons per household & person & $\begin{array}{l}\text { Family Income and Expenditure Survey, Ministry of Public } \\
\text { Management }\end{array}$ \\
\hline expn & Average per capita expenditure & 1,000 yen & $\begin{array}{l}\text { Family Income and Expenditure Survey, Ministry of Public } \\
\text { Management }\end{array}$ \\
\hline qat & Total import quantity of shelled sweet almond & $\mathrm{kg}$ & Japan Exports and Imports, Ministry of Finance \\
\hline vat & Total import value of shelled sweet almond & 1,000 yen & Japan Exports and Imports, Ministry of Finance \\
\hline pat & $\begin{array}{l}\text { Shelled sweet almond CIF (cost, insurance and } \\
\text { freight) price }\end{array}$ & yen $/ \mathrm{kg}$ & Japan Exports and Imports, Ministry of Finance \\
\hline qpt & Total import quantity of pistachio nuts & $\mathrm{kg}$ & Japan Exports and Imports, Ministry of Finance \\
\hline vpt & Total import value of pistachio nuts & 1,000 yen & Japan Exports and Imports, Ministry of Finance \\
\hline ppt & Pistachio CIF (cost, insurance and freight) price & yen/kg & Japan Exports and Imports, Ministry of Finance \\
\hline qwj & Japanese domestic walnut supply & $\mathrm{kg}$ & $\begin{array}{l}\text { Fruits and Vegetables Division, Ministry of Agriculture, } \\
\text { Forestry, and Fisheries }\end{array}$ \\
\hline ta & $1+$ tariff rate for shelled sweet almond & & Japan Exports and Imports, Ministry of Finance \\
\hline tw & $1+$ tariff rate for shelled walnuts & & Japan Exports and Imports, Ministry of Finance \\
\hline tp & $1+$ tariff rate for pistachio nuts & & Japan Exports and Imports, Ministry of Finance \\
\hline cwen & $\mathrm{cwc} / \mathrm{pop} \cdot 1000$ & \multicolumn{2}{|c|}{ dollar/1000 person } \\
\hline qwusn & qwus/pop $\cdot 1000$ & \multicolumn{2}{|c|}{$\mathrm{kg} / 1000$ person } \\
\hline qwen & qwc/pop $\cdot 1000$ & \multicolumn{2}{|c|}{$\mathrm{kg} / 1000$ person } \\
\hline qatn & qat/pop $\cdot 1000$ & \multicolumn{2}{|c|}{$\mathrm{kg} / 1000$ person } \\
\hline qptn & $\mathrm{qpt} / \mathrm{pop} \cdot 1000$ & \multicolumn{2}{|c|}{$\mathrm{kg} / 1000$ person } \\
\hline
\end{tabular}


Table 9. Data Set

\begin{tabular}{|c|c|c|c|c|c|c|c|c|c|}
\hline & cwc & map & $\mathrm{adt}$ & qwus & vwus & pwus & qwe & vwc & pwc \\
\hline 1986 & 400,867 & $4,008,674$ & $4,409,541$ & & & & & & \\
\hline 1987 & 278,920 & $2,611,204$ & $2,890,124$ & & & & & & \\
\hline 1988 & 544,145 & $2,072,883$ & $2,617,028$ & $1,643,222$ & 855,598 & 520.7 & $2,078,082$ & 789,145 & 379.7 \\
\hline 1989 & 385,114 & $1,866,479$ & $2,251,593$ & $1,624,336$ & 951,812 & 586.0 & $1,406,467$ & 552,540 & 392.9 \\
\hline 1990 & 359,776 & $2,426,939$ & $2,786,715$ & $1,989,856$ & $1,222,162$ & 614.2 & $1,365,468$ & 569,908 & 417.4 \\
\hline 1991 & 439,092 & $2,272,606$ & $2,711,698$ & $2,634,974$ & $1,541,461$ & 585.0 & $1,325,904$ & 524,281 & 395.4 \\
\hline 1992 & 425,353 & $1,878,196$ & $2,303,549$ & $3,595,179$ & $2,086,468$ & 580.4 & $1,711,787$ & 664,834 & 388.4 \\
\hline 1993 & 410,709 & $1,515,706$ & $1,926,415$ & $4,600,257$ & $2,913,238$ & 633.3 & $1,862,809$ & 718,817 & 385.9 \\
\hline 1994 & 654,345 & $1,162,786$ & $1,817,131$ & $4,820,892$ & $2,707,646$ & 561.6 & $2,059,216$ & 711,182 & 345.4 \\
\hline 1995 & 654,921 & $1,176,665$ & $1,831,586$ & $6,861,036$ & $2,969,925$ & 432.9 & $1,631,156$ & 445,750 & 273.3 \\
\hline 1996 & 677,449 & $1,119,303$ & $1,796,752$ & $6,862,602$ & $4,505,688$ & 656.6 & $2,246,915$ & 798,876 & 355.5 \\
\hline 1997 & 753,363 & 960,000 & $1,713,363$ & $6,158,167$ & $4,606,002$ & 748.0 & $2,345,094$ & $1,077,548$ & 459.5 \\
\hline 1998 & $1,189,115$ & 724,827 & $1,913,942$ & $6,809,933$ & $4,662,843$ & 684.7 & $1,737,733$ & 813,381 & 468.1 \\
\hline 1999 & $1,013,697$ & 735,355 & $1,749,052$ & $6,940,199$ & $3,594,280$ & 517.9 & $1,596,191$ & 594,507 & 372.5 \\
\hline 2000 & $1,062,121$ & 892,790 & $1,954,911$ & $8,199,784$ & $3,502,023$ & 427.1 & $1,192,445$ & 432,229 & 362.5 \\
\hline 2001 & $1,230,809$ & 812,567 & $2,043,376$ & $7,269,433$ & $4,619,858$ & 635.5 & $1,559,551$ & 638,947 & 409.7 \\
\hline 2002 & 947,544 & 735,755 & $1,683,299$ & $8,447,324$ & $5,029,760$ & 595.4 & $1,461,119$ & 679,534 & 465.1 \\
\hline 2003 & $1,052,500$ & 963,000 & $2,015,500$ & $8,303,890$ & $4,563,271$ & 549.5 & $1,266,673$ & 559,277 & 441.5 \\
\hline & pop & wpif & $\exp$ & $n$ & expn & qat & vat & pat & \\
\hline 1986 & $121,660,000$ & 114.8 & $3,316,493$ & 3.69 & 898,779 & & & & \\
\hline 1987 & $122,239,000$ & 109.2 & $3,371,326$ & 3.67 & 918,617 & & & & \\
\hline 1988 & $122,745,000$ & 108.6 & $3,493,468$ & 3.63 & 962,388 & $24,374,969$ & $10,842,923$ & 444.8 & \\
\hline 1989 & $123,205,000$ & 110.0 & $3,592,205$ & 3.61 & 995,071 & $23,079,779$ & $11,484,947$ & 497.6 & \\
\hline 1990 & $123,611,000$ & 111.4 & $3,734,084$ & 3.56 & $1,048,900$ & $20,507,510$ & $11,610,227$ & 566.1 & \\
\hline 1991 & $124,043,000$ & 111.6 & $3,925,358$ & 3.57 & $1,099,540$ & $22,887,408$ & $10,100,146$ & 441.3 & \\
\hline 1992 & $124,452,000$ & 111.3 & $4,003,931$ & 3.53 & $1,134,258$ & $23,614,853$ & $11,428,762$ & 484.0 & \\
\hline 1993 & $124,764,000$ & 109.5 & $4,022,955$ & 3.49 & $1,152,709$ & $21,618,207$ & $10,687,539$ & 494.4 & \\
\hline 1994 & $125,034,000$ & 108.8 & $4,006,086$ & 3.47 & $1,154,492$ & $18,555,001$ & $10,174,656$ & 548.4 & \\
\hline 1995 & $125,569,000$ & 100.0 & $3,948,741$ & 3.42 & $1,154,603$ & $22,522,468$ & $9,812,629$ & 435.7 & \\
\hline 1996 & $125,864,000$ & 100.6 & $3,946,187$ & 3.34 & $1,181,493$ & $17,913,664$ & $13,129,366$ & 732.9 & \\
\hline 1997 & $126,166,000$ & 99.8 & $3,999,759$ & 3.34 & $1,197,533$ & $18,445,003$ & $12,238,301$ & 663.5 & \\
\hline 1998 & $126,486,000$ & 96.5 & $3,938,235$ & 3.31 & $1,189,799$ & $18,794,912$ & $11,338,175$ & 603.3 & \\
\hline 1999 & $126,686,000$ & 97.8 & $3,876,091$ & 3.30 & $1,174,573$ & $17,298,427$ & $8,101,109$ & 468.3 & \\
\hline 2000 & $126,926,000$ & 95.4 & $3,805,600$ & 3.24 & $1,174,568$ & $21,174,858$ & $7,035,604$ & 332.3 & \\
\hline 2001 & $127,291,000$ & 96.2 & $3,704,298$ & 3.22 & $1,150,403$ & $23,946,198$ & $9,173,329$ & 383.1 & \\
\hline 2002 & $127,435,000$ & 96.1 & $3,673,550$ & 3.19 & $1,151,583$ & $27,827,173$ & $11,182,716$ & 401.9 & \\
\hline 2003 & $127,524,000$ & & & & & $28,734,545$ & $12,262,362$ & 426.7 & \\
\hline
\end{tabular}

\begin{tabular}{rrrrrrrr}
\hline & \multicolumn{1}{c}{ qpt } & \multicolumn{1}{c}{ vpt } & ppt & \multicolumn{1}{c}{ qwj } & ta & tw & tp \\
\hline 1986 & 765,899 & 599,323 & 782.5 & 548,000 & 1.040 & 1.10 & 1 \\
1987 & $2,739,295$ & $1,537,353$ & 561.2 & 558,000 & 1.040 & 1.10 & 1 \\
1988 & $7,102,486$ & $4,461,474$ & 628.2 & 577,000 & 1.040 & 1.10 & 1 \\
1989 & $6,487,078$ & $4,515,114$ & 696.0 & 365,000 & 1.040 & 1.10 & 1 \\
1990 & $5,390,972$ & $3,830,012$ & 710.4 & 502,000 & 1.040 & 1.10 & 1 \\
1991 & $9,488,598$ & $5,508,444$ & 580.5 & 456,000 & 1.040 & 1.10 & 1 \\
1992 & $7,645,719$ & $4,630,433$ & 605.6 & 374,000 & 1.040 & 1.10 & 1 \\
1993 & $6,677,364$ & $3,378,732$ & 506.0 & 319,000 & 1.040 & 1.10 & 1 \\
1994 & $7,686,941$ & $3,179,535$ & 413.6 & 305,000 & 1.040 & 1.10 & 1 \\
1995 & $8,564,876$ & $3,330,032$ & 388.8 & 221,000 & 1.037 & 1.10 & 1 \\
1996 & $6,983,566$ & $3,357,781$ & 480.8 & 223,000 & 1.035 & 1.10 & 1 \\
1997 & $5,123,628$ & $2,982,825$ & 582.2 & 197,000 & 1.032 & 1.10 & 1 \\
1998 & $4,347,970$ & $2,748,878$ & 632.2 & 152,000 & 1.029 & 1.10 & 1 \\
1999 & $3,314,436$ & $1,717,820$ & 518.3 & 221,000 & 1.027 & 1.10 & 1 \\
2000 & $2,929,773$ & $1,636,694$ & 558.6 & $n . a$. & 1.024 & 1.10 & 1 \\
2001 & $3,465,506$ & $1,772,621$ & 511.5 & 100,000 & 1.024 & 1.10 & 1 \\
2002 & $2,695,154$ & $1,560,868$ & 579.1 & 101,000 & 1.024 & 1.10 & 1 \\
2003 & $2,229,651$ & $1,286,277$ & 576.9 & & 1.024 & 1.10 & 1 \\
\hline
\end{tabular}


shelled walnut, shelled sweet almond, and pistachio markets. Tariff elimination of walnut imports to Japan would have increased US exports by $4.7 \%$ and generate 397 million yen gains for Japanese users in 2002 . Japanese users would have gained 4,578 million yen in total at 1995 price levels from tariff elimination of the US walnuts from 1988 to 2002. Negative effects on Japanese walnut farmers will be virtually none because there are only few farmers specialized in walnut production and specialized farmers have their own niche markets almost completely differentiated from imports. This report also revealed that the promotion money collected from US walnut farmers is very effective for increasing exports to Japan, or farmers' incremental gains are over three times higher than their incremental costs.

Table 10. Estimated Results

\begin{tabular}{|c|c|c|c|c|}
\hline & Coefficient & Std. Error & $\mathrm{t}$-Statistic & Critical Level \\
\hline $\mathrm{C}(11)$ & -79.435 & 6.779 & -11.718 & 0.000 \\
\hline $\mathrm{C}(12)$ & -0.478 & 0.167 & -2.872 & 0.006 \\
\hline $\mathrm{C}(13)$ & 6.120 & 0.498 & 12.281 & 0.000 \\
\hline $\mathrm{C}(14)$ & 0.393 & 0.074 & 5.335 & 0.000 \\
\hline $\mathrm{C}(15)$ & 0.121 & 0.070 & 1.733 & 0.090 \\
\hline $\mathrm{C}(21)$ & 0.671 & 0.402 & 1.671 & 0.102 \\
\hline $\mathrm{C}(22)$ & -0.709 & 0.296 & -2.398 & 0.021 \\
\hline $\mathrm{C}(23)$ & 0.407 & 0.200 & 2.036 & 0.048 \\
\hline $\mathrm{C}(24)$ & 0.299 & 0.111 & 2.706 & 0.010 \\
\hline $\mathrm{C}(25)$ & -0.305 & 0.104 & -2.947 & 0.005 \\
\hline $\mathrm{C}(31)$ & 18.840 & 4.863 & 3.874 & 0.000 \\
\hline $\mathrm{C}(32)$ & 0.289 & 0.142 & 2.038 & 0.048 \\
\hline $\mathrm{C}(33)$ & -0.382 & 0.090 & -4.235 & 0.000 \\
\hline $\mathrm{C}(34)$ & -0.938 & 0.346 & -2.716 & 0.009 \\
\hline $\mathrm{C}(41)$ & 70.513 & 18.449 & 3.822 & 0.000 \\
\hline $\mathrm{C}(42)$ & 0.973 & 0.333 & 2.922 & 0.006 \\
\hline $\mathrm{C}(43)$ & -1.491 & 0.434 & -3.434 & 0.001 \\
\hline $\mathrm{C}(44)$ & -4.548 & 1.235 & -3.683 & 0.001 \\
\hline \multicolumn{5}{|c|}{ Equation (1): LOG $(Q W U S N)=\mathrm{C}(11)+\mathrm{C}(12) * \mathrm{LOG}\left(P W U S^{*} T W\right)+\mathrm{C}(13)$} \\
\hline R-squared & 0.954 & Mean dependent var & & 3.594 \\
\hline Adjusted R-squared & 0.936 & S.D. dependent var & & 0.578 \\
\hline S. E. of regression & 0.146 & Sum squared resid & & 0.213 \\
\hline Durbin-Watson stat & 1.168 & & & \\
\hline \multicolumn{5}{|l|}{ Observations: 15} \\
\hline \multicolumn{5}{|c|}{$\begin{array}{l}\text { Equation (2): } \mathrm{LOG}(Q W C N)=\mathrm{C}(21) * \mathrm{LOG}\left(P W U S^{*} T W\right)+\mathrm{C}(22) * \mathrm{LOG}(P W C \\
\quad * T W)+\mathrm{C}(23) * \mathrm{LOG}(P A T * T A)+\mathrm{C}(24) * \mathrm{LOG}(C W C N)+\mathrm{C}(25) \\
\quad * \mathrm{LOG}(C W C N(-1))\end{array}$} \\
\hline R-squared & 0.690 & Mean dependent var & & 2.573 \\
\hline Adjusted R-squared & 0.578 & S.D. dependent var & & 0.210 \\
\hline S.E. of regression & 0.136 & Sum squared resid & & 0.204 \\
\hline Durbin-Watson stat & 2.053 & & & \\
\hline \multicolumn{5}{|l|}{ Observations: 16} \\
\hline $\begin{array}{l}\text { Equation (3): LOG(Q } \\
\quad * \text { LOG }\left(P A T^{*} T A\right)\end{array}$ & $\begin{array}{l}A T N=\mathrm{C}(31) \\
-\mathrm{C}(34) * \mathrm{LOG}\end{array}$ & $\mathrm{G}\left(P W C^{*} T W\right)+\mathrm{C}(33)$ & & \\
\hline $\mathrm{R}$-squared & 0.582 & Mean dependent var & & 5.136 \\
\hline Adjusted R-squared & 0.468 & S.D. dependent var & & 0.138 \\
\hline S.E. of regression & 0.101 & Sum squared resid & & 0.112 \\
\hline Durbin-Watson stat & 1.102 & & & \\
\hline \multicolumn{5}{|c|}{ Observations: 15} \\
\hline \multicolumn{5}{|c|}{$\begin{array}{l}\text { Equation (4): LOG }(Q P T N)=\mathrm{C}(41)+\mathrm{C}(42) * \mathrm{LOG}(P A T * T A)+\mathrm{C}(43) * \operatorname{LOG}(P P T) \\
\quad+\mathrm{C}(44) * \mathrm{LOG}(E X P N)\end{array}$} \\
\hline R-squared & 0.556 & Mean dependent var & & 3.773 \\
\hline Adjusted R-squared & 0.434 & S.D. dependent var & & 0.417 \\
\hline S.E. of regression & 0.314 & Sum squared resid & & 1.084 \\
\hline $\begin{array}{l}\text { Durbin-Watson stat } \\
\text { Observations: } 15\end{array}$ & 1.095 & & & \\
\hline
\end{tabular}

Notes. Estimation Method: Seemingly Unrelated Regression. Sample: 1988 to 2003. 